\title{
Fionnuala Walsh, Irish Women and the Great War
}

\section{Sylvie Kleinman}

\section{(2) OpenEdition}

\section{Journals}

\section{Édition électronique}

URL : https://journals.openedition.org/etudesirlandaises/12139

DOI : 10.4000/etudesirlandaises.12139

ISSN : 2259-8863

\section{Éditeur}

Presses universitaires de Caen

\section{Édition imprimée}

Date de publication : 30 décembre 2021

Pagination : 158-160

ISBN : 978-2-84133-157-0

ISSN : 0183-973X

\section{Référence électronique}

Sylvie Kleinman, «Fionnuala Walsh, Irish Women and the Great War », Études irlandaises [En ligne], 46-2 I 2021, mis en ligne le 17 décembre 2021, consulté le 04 novembre 2022. URL : http://

journals.openedition.org/etudesirlandaises/12139; DOI : https://doi.org/10.4000/etudesirlandaises. 12139

\section{(c) (i) (2)(2)}

Creative Commons - Attribution - Pas d'Utilisation Commerciale - Partage dans les Mêmes Conditions 4.0 International - CC BY-NC-SA 4.0

https://creativecommons.org/licenses/by-nc-sa/4.0/ 
bien la fiction (roman policier ou récit de voyage à pied) que la poésie, et il prend en compte des productions de l'île d'Irlande dans son ensemble. Sans prétendre couvrir l'ensemble de la littérature contemporaine irlandaise, le choix d'œuvres commentées permet de saisir l'ampleur et la variété d'une production littéraire sans cesse renouvelée. L'étude de Catherine Conan propose un éclairage théorique rafraîchissant, une nouvelle optique, au sens où l'entend Karen Barad: plutôt qu'un miroir du monde, la littérature est envisagée comme un dispositif de diffraction du monde, qui relie et entrelace les textes et les situations, l'espace et les pratiques, les sujets et les objets.

Grâce à une structure rigoureuse, et un propos d'ensemble d'une grande clarté, l'ouvrage donne à lire une carte à la fois familière et nouvelle de la littérature contemporaine d'Irlande. Le tout est vif et maîtrisé; l'écriture précise et élégante; les concepts déployés toujours stimulants. Cet ouvrage constitue indéniablement une référence sur la littérature irlandaise contemporaine, dont les lecteurs non francophones ne pourront que regretter qu'il ne soit pas publié en anglais.

Anne Goarzin

\section{Fionnuala Walsh, Irish Women and the Great War, Cambridge, Cambridge University Press, 2020, 277 p.}

The book is an essential contribution to our understanding of the transformative impact of World War I on the lives of women in Ireland. The war itself had been the subject of a form of social amnesia in Ireland, from which both academic and public history began emerging in the 1990s, most notably for and during the Decade of Centenaries (2013-2023). Fionnuala Walsh's comprehensive study is thus ground-breaking, and reflects the recent emergence of war studies in Ireland while adopting a gendered war and society focus. But it also sits easily within the thriving international scholarship on the period, moving beyond national boundaries and consistently making transnational comparisons. It is a compelling demonstration of how women's lives in Ireland, in transformation since the 1880s, were irrevocably changed by their varied experiences of the war.

Six chapters explore core areas impacting on women's lives. No differently than in other combatant countries, women immediately responded and mobilised, taking on auxiliary military roles, and nursing and voluntary aid on the home front. But with the island on the brink of civil war in July 1914, women had in fact already been active in a quasi-militarised society, aiding unionist and nationalist militias. Though there was evidently opposition to a perceived British war effort, there were also opportunities to avail of. The skills acquired in the abundant classes, lectures and training schemes would ensure advanced nationalist women could later participate meaningfully in the 1916 Rising (though the number of combatants was minimal). Walsh considers class - the majority of surviving ego-documents 
reflect an upper-class bias - and religion; she consciously avoids treating women as a homogeneous group. Previous assumptions about popular support for the war effort are challenged: while Protestants dominated the voluntary war effort, Catholic women defied their hierarchy and mobilised, forming the majority in the Women's services. Further chapters examine family, welfare and domestic life, social morality as women's visibility in the public sphere increased, working lives, politicisation and demobilisation. Consistently, urban-rural and regional divergences are considered, as are the multiple challenges faced by ordinary women. While farming families prospered, food shortages and a doubled cost of living brought hardship to urban workers, though women gained greater control of family income and their domestic budget. Issues of welfare became politicised, as republicans increasingly pointed to the perceived negative consequences of British rule in Ireland, e.g. food supply, infant welfare, urban tenements, as the war meant greater state intervention in the domestic sphere.

Women's lives are located within the general social conditions of the day, and how the war transformed their already increased visibility in the public sphere. Not only were anxieties about female moral and social behaviour accentuated, especially scrutinised were soldier's wives receiving a separation allowance, one in many ways the (British) state took on the role of surrogate husband. Though in popular consciousness these separation women are linked to vocal condemnation of the 1916 rebels in Dublin, this is a robust study firmly rooted in pertinent sources. From the wartime press emerges a widespread belief in an endemic problem of fraudulent claims, child neglect and drunkenness among soldier's wives. But due to the numbers of men mobilised, there were more female criminal drunkards, if the overall wartime number of females arrested declined. Furthermore, Walsh demonstrates that against the backdrop of state and social surveillance confining women to strictly-defined behavioural codes, anxiety surrounding women's behaviour was inseparable from their increased visibility in the workplace. In agriculture, domestic service, clerical work, munitions (mostly in an around Belfast), the railway industry and the medical professions, the emancipatory nature of women's war work is examined. Many women seized new opportunities to move away from traditional gendered employment (i.e. domestic), but because Irish men were not conscripted, there was less of a need for women to substitute for them. Lasting legacies of the war were the strengthening of the labour movement, improved working conditions for women and the increased awareness of their economic importance, as well as their acceptance in previously male-only unions.

Given the tense relationship with Britain, the participation of Irish women in a range of activities may surprise us as high, but this may reflect more on their self-perception as having a meaningful role to play in society generally, and a heavily politicised one at that, than on political allegiance. Supporting the war effort emphasised underlying conflicts, and evolved over time; it also divided suffragists, spread over the island's political ideologies. The North-South divide was deepened, and Irish national and British imperial identities irreversibly polarised. Unionists used the war work of women to underscore their loyalism, while nationalist and 
republican dissent against aiding the war effort progressed. If in 1914 many groups mobilised to support a government they had been opposing at every turn, they also saw opportunities for politicisation. For some, the war created a new dynamic for subversion and dissent, e.g. disruption at recruitment meetings and organisation of anti-recruitment ones. If on a macro-historical scale, the 1916 Rising and its immediate aftermath irreversibly transformed Irish nationalism, it also brought the war home to an island which had not witnessed it for just over a century. It gave women of all ideological shades trained in first aid their first experience of genuine conflict. Traditional assumptions of gendered roles were toppled by the prominent participation of women in the Rising, then opposition to conscription in the last two years of the war would be the final issue unifying republicans and nationalists prior to independence. Women, already agitators or previously unorganised, were heavily and publically involved.

Female citizenship in the 1920s may have been defined by motherhood and domestic life, but the war had given Irish women prominence in the public sphere, where they had defended their interests and that of their families. The book is devoid of illustrations and aimed at an academic audience, but Walsh's prose is fluid and credible. The focus is anything but insular and arguments are well supported by scrupulous research. Until now, except for specialised studies, the multiple ways in which Irish women of all backgrounds had experienced the Great War and its aftermath had remained in the shadows of history.

Sylvie KLEINMAN

\section{Cian T. McMahon, The Coffin Ship: Life and Death at Sea during the Great Irish Famine, New York, New York University Press, 2021, 315 p.}

The Great Irish Famine has long sparked a plethora of highly sensitive debates as to the actual numbers of fatalities and as to the real more or less concerted responsibilities lying behind one of the worst tragedies that occurred in Europe in the $19^{\text {th }}$ century. As often noted, this catastrophe happened right in the middle of one of the wealthiest, most powerful empires that human history had ever known so far: the British Empire. As for now, retrospectively the coffin ship mentioned in the title has turned into a symbol, not to say a tell-tale trope, an emblematic element in history that is supposed to sum it all up and is part and parcel of that grim narrative that may turn out to be strewn with "tired clichés, half truths, and dry statistics" (as the blurb posits in the front cover). Landmark books on the subject have been published to shed light on the Irish Famine, such as Cecil Woodham-Smith's (1962) The Great Hunger: Ireland 1845-49, or Cormac Ó Gráda's 1989 seminal book entitled The Great Irish Famine, or more recently The History of the Irish Famine (vol. I: The Great Irish Famine) edited by Christine Kinealy, to name but a few amongst a wealth of studies conducted by historians searching through governmental archives 